Témoigner Témoigner. Entre histoire et mémoire

Getuigen Revue pluridisciplinaire de la Fondation Auschwitz

$122 \mid 2016$

Révisionisme et négationisme

\title{
Het veranderlijke gelaat van de slachtoffers: Beelden van leed in Cambodja (1975-2013)
}

\section{Vicente Sánchez-Biosca}

Traducteur : Gorik de Henau

\section{(2) OpenEdition \\ Journals}

\section{Édition électronique}

URL : https://journals.openedition.org/temoigner/4553

DOI : $10.4000 /$ temoigner.4553

ISSN : 2506-6390

\section{Éditeur :}

Éditions du Centre d'études et de documentation Mémoire d'Auschwitz, Éditions Kimé

\section{Édition imprimée}

Date de publication : 2 mai 2016

Pagination : 114-129

ISSN : 2031-4183

Référence électronique

Vicente Sánchez-Biosca, «Het veranderlijke gelaat van de slachtoffers: Beelden van leed in Cambodja (1975-2013)», Témoigner. Entre histoire et mémoire [Online], 122 | 2016, Online op 30 septembre 2021, geraadpleegd op 05 janvier 2022. URL: http://journals.openedition.org/temoigner/4553 ; DOI: https:// doi.org/10.4000/temoigner.4553 


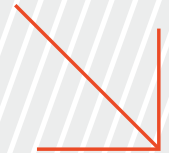

$\rightarrow$ Vicente Sánchez-Biosca

Universitat de València

Vertaling: Gorik de Henau

(1) Mijn dank gaat uit naar Ben Kiernan (Yale University) voor de vriendelijke wijze waarop hij mijn talrijke vragen beantwoordde en me heel wat aanwijzingen gaf. Toen ik daar de leerstoel Spanish Culture and Civilization bekleedde (winter-lente 2013), stelde het King Juan Carlos I Center aan New York University (en zijn directeur Jo Labanyi) me in de gelegenheid om het symposium The Desire to See: the Production and Circulation of Images of Atrocity te organiseren (april 2013); gedurende de voorbereiding en het verloop daarvan kregen bepaalde van de hier uiteengezette ideeën vorm. Tijdens mijn verblijf in New York leerde ik dankzij het festival Season of Cambodia. A Living Arts Festival (april-mei 2013) het werk van hedendaagse kunstenaars van de derde generatie kennen, waarmee die de ervaring van de genocide herschreven. Op het congres Creation and Postmemory (Columbia University, 10-12 april) werd de reflectie in de context van de Shoah, Rwanda en grensoverschrijdende rechtspraak gesitueerd, waarbij de aandachtspunten van het seminarie over postmemory onder leiding van Marianne Hirsch werden gevolgd.

\section{Het veranderlijke gelaat van de slachtoffers Beelden van leed in Cambodja $(1975-2013)^{1}$}

\begin{abstract}
De tijd, dat transparante medium waarin mensen worden geboren, zich voortbewegen en verdwijnen zonder een spoor achter te laten.
\end{abstract}

(Vasili Grossman, Leven en lot)

\author{
L'homme en péril de mort, quand les conditions \\ le permettent, prend le parti de sympathiser \\ avec ceux qui le menacent.'
}

(François Bizot, Le silence du bourreau)

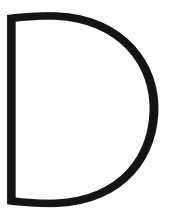

oor voormalige gevangenissen, herdenkingsmusea en gedenkcentra (in de eerste plaats die gewijd aan de Holocaust) te bezoeken, zijn moderne ramptoeristen vertrouwd geraakt met galerieën, vertrekken en muren die vol hangen met gezichten van slachtoffers, gefotografeerd vanaf de taille of in close-up, soms frontaal en in profiel, zoals in de tweede helft van de negentiende eeuw bepaald door de zogenaamde bertillonnage. Dergelijke mozaïeken suggereren een bijzondere synthese tussen het individuele en het collectieve, en met hun strategische opstelling wordt beoogd de voordelen van het eerste te combineren met de impact van het tweede: door de opeenhoping van gezichten wordt de in statistisch opzicht monsterlijke dimensie onderstreept van de misdaad die in dergelijke plekken wordt herdacht, terwijl elk beeld je aanspreekt alsof het om één man of vrouw ging. Terwijl je al kijkend door vestibules, gangen en koepels 
(3) In wat volgt, gebruiken we de benaming Tuol Sleng om te verwijzen naar de plek en het museum, en reserveren we S-21 om te refereren aan de gevangenis en het foltercentrum tijdens de Rode Khmerperiode.

(4) Nhem Ein, een van de fotografen van S-21, heeft zich de voorbije decennia tot een regelrechte mediaster ontpopt. Hij werd op jonge leeftijd naar China gestuurd om daar een fotografische opleiding te krijgen. Dit personage, dat niet het minste berouw toont en zonder scrupules bereid is om eigen en andermans materiaal te verkopen, wilde zelfs in zijn streek Anglong Veng een herdenkingsmuseum over de Rode Khmerperiode openen. Hij blijft ervan overtuigd dat hij belangrijk werk verrichtte en dat de mensheid hem daarvoor erkentelijk zou moeten zijn. moesten de toenemende zuiveringen tegen dissidenten en 'verraders' van het regime worden afgehandeld. Naarmate het land zich hermetisch afsloot ten gevolge van de economische mislukkingen van het regime en de nieuwe bedreigingen vanwege Vietnam en de Sovjet-Unie, kreeg de samenzweringsparanoia de bestuurders in haar greep en Tuol Sleng, bekend als S-21 ${ }^{3}$, werd een van de zenuwcentra van de repressie.

Dit gezegd zijnde merk je, als je die gezichten in de ruimten van het actuele museum van nabij bekijkt, dat de ogen van de gedetineerden bezield lijken door emoties die even divers als moeilijk te doorgronden zijn: sommigen lijken verrast, anderen aan hun lot overgelaten; sommigen vertonen nog de sporen van recente foltering, terwijl je zou zeggen dat anderen gelaten aanvaarden wat hen te gebeuren staat. Hoe dan ook, bij nader toezien komt de blik waarmee al die mensen je aankijken niet voort uit hun slachtofferschap; integendeel, in wezen draagt die het verradersstatuut mee waarmee ze door de fotocamera werden vastgelegd. Precies op het ogenblik dat ze hun ogen naar de camera richtten en dat die hen op de gevoelige plaat vastlegde, hadden deze figuren niets van wat we ze nu zonder aarzeling toekennen: het statuut van slachtoffer. Ze waren net het tegenovergestelde, namelijk schuldigen.

Ten langen leste verbaast de vanzelfsprekendheid waarmee hun status in zijn tegendeel is veranderd, zonder enige inhoudelijke verandering. Hoe is het, in het licht van de tijd, plaats en emoties die uit deze foto's spreken, mogelijk dat werd voorbijgegaan aan de blik die ze schiep? De scène is historisch nochtans goed gedocumenteerd: de gevangene, die vaak van zeer ver per vrachtwagen werd vervoerd, werd door zijn gevangennemers in een ruimte geworpen; de blinddoek werd afgerukt om de foto te nemen ${ }^{4}$. Die vluchtige cameraklik heeft een onvergankelijk spoor achtergelaten dat de tijd heeft doorstaan: de foto zelf. Hoe pover en ontoereikend die ons mag toeschijnen, toch is het cruciaal haar te onderzoeken om het gebaar te begrijpen dat aan het archief ten grondslag ligt - de blik die het doet ontstaan. Want in die bewaard gebleven foto van de gedetineerde wordt de plotselinge botsing van twee blikken in scène gezet.

\section{VIJANDEN: DE STICHTENDE BLIK}

Op het moment waarop ze werden genomen, identificeerden deze foto's geduchte vijanden, vermeende (later onder foltering bekend hebbende) spionnen van de KGB of de CIA (of van beide tegelijk), saboteurs van de revolutie of partij-infiltranten. In de verbeeldingswereld van de Rode Khmers werd S-21 een gevangenis voor maximale veiligheid, bestemd voor in ongenade gevallen hoge partijfunctionarissen, dit in tegenstelling tot andere foltercentra in het land waar nochtans ook heel wat gedetineerden verbleven (inclusief bejaarden, kinderen en vrouwen) wier lot zich in het spinnenweb van het complot had bespoedigd. Je zou kunnen stellen dat S-21 het authentiekste product was van de kosmologie van de Rode Khmers, van hun drang om hun tegenstanders te ontmaskeren, op fiches te zetten, te onderdrukken en uit te roeien. Maar om dat te begrijpen moeten we doordringen in de archieflogica van de auteurs en hun functie in het vernietigingsproces, het noodzakelijke correlaat van de 
constructie van de nieuwe utopie. Vandaar een paar noodzakelijke vragen: hoe ging dat fotograferen in zijn werk? In welke reeks acties vond het plaats? Waarom werd een foto van de gedetineerde genomen, terwijl die toch meteen zou worden terechtgesteld? Met welke bedoeling werd de foto bewaard? Welke andere documenten makkten het criminele archief compleet? Deze vragen moeten worden beantwoord, willen we begrijpen welke rol de fotografie tijdens het proces precies speelde.

Vandaag weten we dat de gevangenen van S-21 al bij hun aankomst tot de dood waren veroordeeld. De fotografische daad maakte deel uit van een hele reeks, ingebed in een stelsel van een onverbiddelijke oorzakelijkheid: aanhouding en transport naar die semi-clandestiene ruimte in een verlaten stad ${ }^{5}$; op fiche zetten door de naam in te schrijven en een nummer toe te wijzen dat gewoonlijk op de borst van de gedetineerde werd aangebracht; foto nemen, waarop de ogen plotseling opengingen door het verblindende licht; vervolgens werd de gevangene met stangen aan voetboeien vastgemaakt en vervoerd naar een gemeenschappelijke cel die hij of zij alleen verliet voor geregelde ondervragingen, met eerst de zogenaamd 'politieke' fase (discussie, overreding), dan de 'hete' fase vol fysieke martelingen en ten slotte, als de ondervraagde helemaal weigerde mee te werken, de 'helse' fase die een ongewenste dood kon veroorzaken ('als de gevangene sterft, gaat het document verloren', luidde een slogan van de centrumverantwoordelijke). De duur varieerde naargelang het belang of het verzet van de verdachte, maar werd altijd nauwlettend in de gaten gehouden door Kaing Guek Eav (alias Duch), de efficiënte directeur, die angstvallig en eigenhandig instructies opschreef die moesten leiden tot het verkrijgen van een bevredigende bekentenis. Zodra dit was gelukt, bepaalde hij met zijn pietepeuterige en perfecte schoonschrift het moment van de 'eliminering' die, behoudens uitzondering, werd voltrokken in de velden van Choeung Ek, waar de veroordeelde 's nachts per vrachtwagen werd heengebracht. Verlicht door een aggregaat werd hij geblinddoekt naar de rand van een kuil gevoerd, waar hij knielde en met een ijzeren staaf een dodelijke klap op het hoofd kreeg; nadat hij in de kuil was gevallen, sneed een andere beul hem de strot af. In uitzonderlijke gevallen, op grond van het belang van bepaalde terechtgestelden, kreeg Duch van zijn superieur Son Sen het bevel om het lijk te fotograferen. Zo verzekerden ze zich ervan dat de dreiging die van de terechtgestelde uitging definitief was bezworen.

In die zin maakte de fotografische daad deel uit van een strikte keten die, als ze zou worden verbroken, de granieten stabiliteit van de Rode Khmermacht zou bedreigen. Want volgens de logica van de leiders en functionarissen vochten ze tegen muitende agenten die in binnen- en buitenland over spionagenetwerken beschikten. Zo beschouwd werden met de verkregen foto's geen beschuldigden of verdachten, maar schuldigen gearchiveerd. Korte tijd later werden diezelfde positieven tot klein formaat bijgeknipt en bij een fiche gevoegd die de criminele biografie van elke gevangene omvatte. Er was geen twijfel over mogelijk: zowel voor slachtoffers als beulen vormden de foto's ondubbelzinnige tekenen van de macht en doeltreffendheid van het regime (Hughes 2003, 25). De fotograaf Nic Dunlop noemde de fotografische daad daarom een trial by camera (berechting door de camera). Op basis van dat alles
(5) Nadat de stad was ingenomen werd Phnom Penh in april 1975 geëvacueerd. Met het opblazen van de nationale bank, het afschaffen van geld en scholen en het sluiten van de ziekenhuizen was de uittocht naar het platteland begonnen, naar de zuivere oorden waar het oude volk woonde, de klasse waarop de landelijke revolutie van de Rode

Khmer moest worden gefundeerd (Kiernan 1996). 


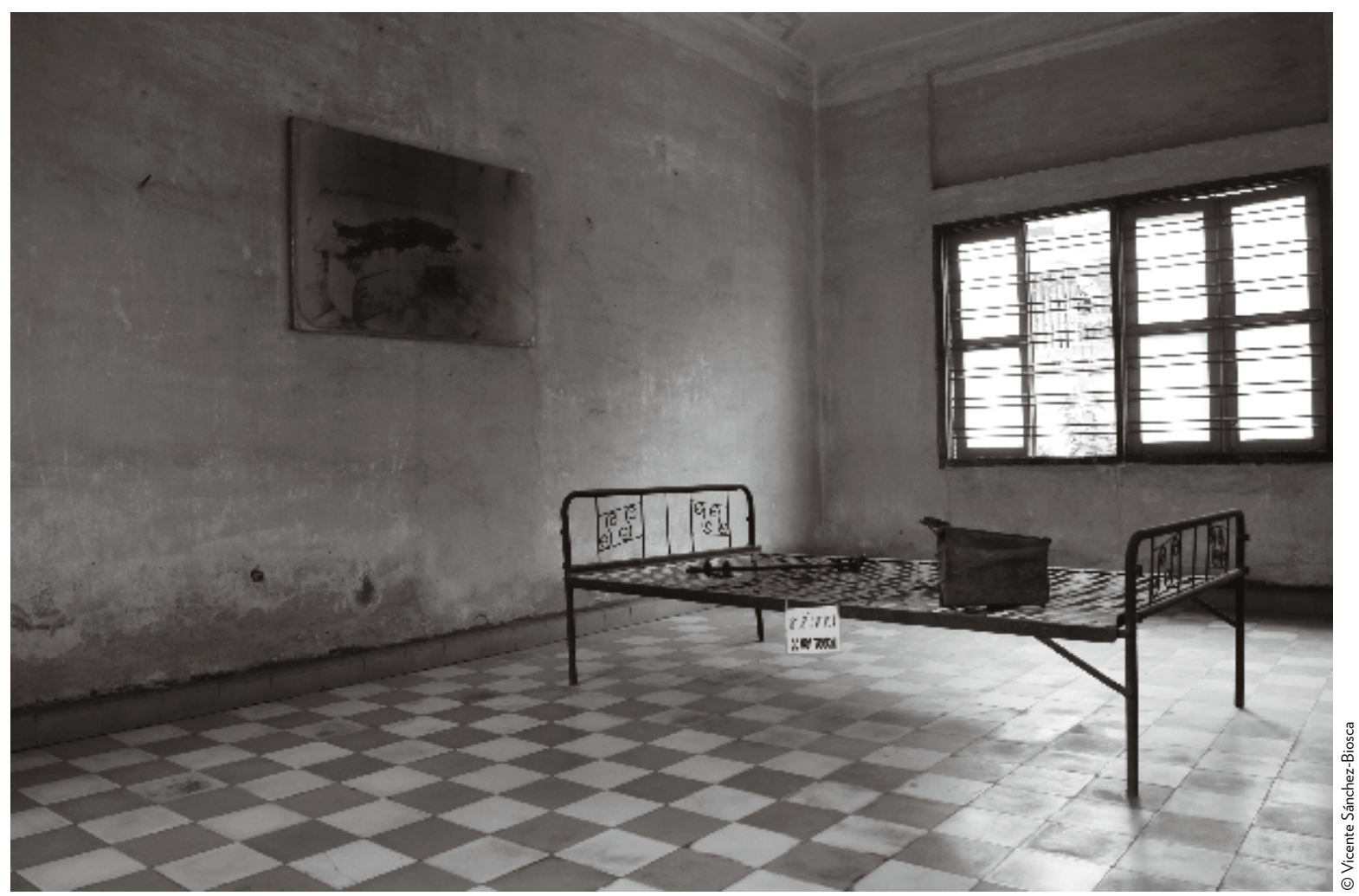

_Cel in gebouw A van Tuol Sleng. Het bed met foltertuigen werd zo aangetroffen door de Vietnamese strijdkrachten in januari 1979. Aan de muur zien we een foto van het lichaam dat in de kamer werd ontdekt. kun je gerust besluiten dat de geschiedenis van de Cambodjaanse communistische partij net die opeenvolging van complotten was. De foto's archiveren en bewaren was een manier om de geschiedenis van de revolutie, haar tegenstanders en haar overwinningen neer te schrijven.

\section{TWEEDE BLIK: EEN GRUWELMUSEUM}

In januari 1979 trokken Vietnamese troepen van de zevende divisie Phnom Penh binnen, het hoogtepunt van een offensief dat een paar weken voordien was gepland. Op hun weg vonden ze een apocalyptische sfeer, die de oorlogsverslaggever Ho Van Thay en zijn team op foto en film vastlegden.

De geopolitieke situatie in de regio was sinds 1977-1978 zeer complex geworden en zou de volgende jaren nog verslechteren ten gevolge van het machtsevenwicht: door de scheuring binnen het communistische blok - Vietnam was een bondgenoot van de USSR, de Rode Khmers kregen steun van China - brak de Vietnamees-Cambodjaanse oorlog uit. Zodra de Vietnamese overwinning een feit was, zetten de bezettingstroepen alles in het werk om te bewijzen dat de in Democratisch Kampuchea gepleegde misdaden helemaal niet het werk waren geweest van communisten, maar van sadistische leiders die zich door hun daden familie toonden van de nazi’s. De 
operatie was niet gemakkelijk te orkestreren en moest in de eerste plaats de internationale gemeenschap aanspreken. Om die reden nodigde de pas opgerichte Volksrepubliek Kampuchea op 25 januari 1979, nauwelijks drie weken nadat de hoofdstad was ingenomen, journalisten van socialistische landen naar Tuol Sleng uit; onder anderen de beroemde Oost-Duitse documentairemakers Walter Heynowki en Gerhard Scheumann genoten van alle faciliteiten voor hun film Kampuchea-Sterben und Auferstehen (Cambodja, dood en opstanding, 1980), met opnamen van Ho Van Thay. De strategie van de Vietnamezen bestond erin dat ze niet verborgen wat ze hadden gevonden, maar in de voetsporen van de barbarij een belastend relaas construeerden waarmee ze de Rode Khmers uit de communistische familie wilden verbannen en hen afschilderen als een criminele bende die de genocide van haar eigen volk had uitgevoerd. Daartoe koos de nieuwe regering een strategie die pijnlijk moest zijn voor de ogen en schokkend voor de geest. Het huiveringwekkendste resultaat daarvan was het Museum of Genocidal Crimes, dat in januari 1980 zijn deuren opende ${ }^{6}$.

Mai Lam, directeur van het Museum of American War Crimes in Ho Chi Minh City (1975), werd met het inrichten van het museum belast. Zelfs al had Lam Auschwitz bezocht om inspiratie op te doen, zijn formule was meer visceraal dan subtiel, trouw aan het model dat vier jaar eerder in het voormalige Saigon was uitgetest, namelijk een gruwelkamer. Hoewel de leiding officieel in handen was van Ung Pech, een Cambodjaanse overlevende, trad Lam achter de schermen als éminence grise op. Het museum koos ervoor om enerzijds het collectieve te benadrukken en anderzijds zijn toevlucht te nemen tot details om het macabere te beklemtonen: zo werden marteltuigen tentoongesteld, het metalen bed uitgestald waarin het lijk was gevonden van een man die in zijn eigen bloed baadde, en hingen overal foto's van slachtoffers. Het was Lams bedoeling (en die strategie haalde het) om de toeschouwer een pathetische ervaring van het trauma te bezorgen, waarbij de cognitieve elementen werden weggelaten. Dat blijkt ook uit het bijna volledig ontbreken van informatieve opschriften (Violi 2010, 38). Niets drukte de gekozen stijl beter uit dan het opstellen van een reusachtige kaart van het land met de schedels van slachtoffers, waarop de rivieren schokkend genoeg waren weergegeven met een bloedrode draad (later werd deze naargeestige kaart verwijderd en vervangen door een fotografische kopie). Maar ook andere, aanvullende strategieën werden uitgeprobeerd. In 1980 werd de overlevende Vann Nath - een schilder die zijn hachje had weten te redden doordat hij Pol Pot zo goed kon neerzetten in muurschilderingen - aangesteld om gevangenisscènes op het doek te reproduceren (Vann Nath 2008, 161; Tranche 2011). Zijn ontstellende werken, waarin hij het documentaire combineerde met een getuigenis over de gruweldaden van het leven in $\mathrm{S}-21^{7}$, waren opgevat in een naïeve stijl en werden in het museum opgenomen; een jaar later voegde de beeldhouwer Bou Meng, nog een overlevende, zich bij het team.

Tijdens het Vietnamese protectoraat waren er heel wat diplomatieke, humanitaire en politieke overlappingen. De voormalige Rode Khmers, die teruggetrokken in het oerwoud op een gunstige situatie wachtten, werden door de Verenigde Naties en de Verenigde Staten nog altijd erkend als de legitieme regering van het land,
(6) Omdat de Vietnamese strategie in het begin op de internationale socialistische pers (Cuba, USSR, Oost-Duitsland enz.) was gericht, werd de Cambodjaanse bevolking tot juli 1979 niet in de gevangenis toegelaten.

(7) Het is onmogelijk dat Vann Nath de scènes die hij schilderde daadwerkelijk had gezien, want hij kwam geblinddoekt ter plaatse en bracht zijn dagen door in de studio, waar hij schilderde onder het waakzame oog van Duch. Hij kreeg de verhalen van anderen te horen. Bijgevolg is zijn waarde als getuige te danken aan zijn persoon en speelt ook de verbeelding een bepaalde rol. 
vermits Vietnam als de voornaamste vijand gold. De Vietnamese terugtrekking in 1989 verlichtte al evenmin de situatie: in de verdragen van Parijs uit 1991 werd een nationale-verzoeningsretoriek verdedigd waarin uiterst omzichtig werd verwezen naar de misdaden van Democratisch Kampuchea. Toch werden in dezelfde periode nog andere initiatieven opgestart die op lange termijn vrucht zouden dragen: in 1982 begonnen mensenrechtenactivisten David Hawk en Gregory Stanton actief te zoeken naar bewijsmateriaal voor een eventuele berechting van de Rode Khmerleiders; de eerste richtte het Cambodian Genocide Project op, de tweede de Cambodian Documentation Commission. Dergelijke activiteiten, eerst achter de schermen, later in de openbaarheid, brachten een verandering van perspectief met zich mee, wat zich vertaalde in een nieuwe kijk op de personen die door de Rode Khmermachinerie waren gefotografeerd.

\section{BLIKKEN, BIOGRAFIEËN, VERSLAGEN}

In de mazen van de internationale diplomatie werd via universitaire projecten en privé-initiatieven begonnen met het nauwgezet vergaren van documenten en het optimaliseren van informatie. In 1988 zette Judy Ledgerwood in samenwerking met John Badgley het Cornell University's Microfilming Project op, met de bedoeling om het overvloedige bewijsmateriaal uit S-21, dat werd verwaarloosd en dreigde te verdwijnen, te inventariseren en te bewaren. In september 1989 kregen ze toelating om de ampele documenten van dat centrum op microfilm te zetten. Op initiatief van historicus Ben Kiernan richtte de Noord-Amerikaanse Yale University in 1994 dan weer het Cambodia Genocide Program op, dat in januari 1995 een kantoor opende in Phnom Penh: het Documentation Center of Cambodia (DC-Cam). Aan het hoofd daarvan werd de Cambodjaans-Amerikaanse Youk Chhang aangesteld, een overlevende van de genocide en, via de taak die hij op dat moment aanvatte, de drijvende kracht achter de grote processen die tussen 2009 en 2013 plaatsvonden. Met zijn initiatieven trachtte hij vooruitgang te boeken in een mijnenveld: er rezen dreigementen om het beheer van Tuol Sleng financieel droog te leggen en zelfs om het museum te sluiten, terwijl de documenten ter plekke beschadigd werden en zelfs zoekraakten; na de verdragen van Parijs en de aansluitende oprichting van de United Nations Transitional Authority in Cambodia (UNTAC, 1992-1993) ontstond de neiging om het verleden omtrent de volkerenmoord uit de weg te gaan. Intussen trachtten de Rode Khmers herhaaldelijk te hergroeperen, tot ze in 1998 definitief de wapens inleverden.

In dat klimaat van twijfel en achterdocht begonnen de fotografen Chris Riley en Douglas Niven in 1993 aan de taak om de negatieven die in een opslagruimte in Tuol Sleng werden gevonden op te poetsen, te catalogeren en er nieuwe kopieën van te verkrijgen, samen met ander belangrijk en tot op dat ogenblik onbekend documentatiemateriaal. Na drie jaar restaureren en inventariseren wisten ze met hun Photo Archive Group nieuwe perspectieven te openen om de identiteit van de slachtoffers te ontsluieren en werd een alternatieve blik mogelijk: elke foto werd 
onderzocht, uit elk gezicht een sprankje gekortwiekt leven losgewrikt, en de kleine of grote verschillen met andere foto's opgetekend. Ook andere initiatieven, op het vlak van literatuur, getuigenis en film, waren erop gericht om het collectieve aspect van het lijden, dat door de propvolle panelen van S-21 was opgedrongen, meer naar de achtergrond te dringen. Alleen of met behulp van andere biografische documenten schonken de kunstenaars het slachtoffer zo een vluchtige ademtocht terug, waarmee die de toeschouwer kon toeroepen vanuit het halfduister van een kunstzaal, de bewegende schaduwen van een film of vanaf de pagina van een catalogus. Enerzijds stelde de intrusie in musea en kunsttentoonstellingen een moreel probleem: waar liggen immers de grenzen van de kunst met betrekking tot de representatie van menselijk lijden (De Duve 2008)? Anderzijds bleek het mogelijk om via verhalen het menselijke weefsel te herstellen dat de Rode Khmers hadden kapotgemaakt, door de brokstukken van een tragisch verleden weer bij elkaar te rapen en het land te helen. Exemplarisch in dit verband is het geval van de jonge Hout Bophana, die vanwege haar liefdesbrieven ter dood werd veroordeeld. Om kort te gaan, twee blikken (museaal en narratief, literair dan wel filmisch) stemden ondanks hun verschillende uitdrukkingsmiddelen toch overeen. Allebei hadden ze de bedoeling om de toenmalige periode te benoemen, weer te geven en te overdenken - een periode los van de schoolboeken, buiten de actieradius van de rechtbanken en afwezig uit het openbare rouwbeklag.

Een van die blikken (de derde in onze opsomming) gaat terug op de resultaten van de reeds genoemde Photo Archive Group. De recuperatie van de negatieven liet toe om van naderbij te bestuderen wat voordien onopgemerkt was gebleven, namelijk de verschillen tussen de originele foto en de bijgeknipte beelduitsnede van de gedetineerdenfiches, waaruit de achtergrondruis was verwijderd. ${ }^{8}$ Geïsoleerd en tentoongesteld in een museum bracht de fotografische kopie een andere perceptie teweeg door de zichtbaarheid van details: bepaalde buitenopnamen van de gevangenis weerleggen bijvoorbeeld dat alle foto's binnenskamers zouden zijn genomen. Als het laboratorium daartoe is ingericht onthult een ruisdetail, zoals de arm van een baby die aan de onderrand van de beelduitsnede zichtbaar wordt, dat de vrouwen met hun kinderen werden gefotografeerd; een tweede gedetineerde die is vastgemaakt aan de gefotografeerde helpt om te begrijpen dat ze aan elkaar waren vastgebonden... Al die scenografische fragmenten, voor zover ze verder of minder ver gingen dan het simpele portret, vergrootten de kennis over het hier en nu waarin de identificatie plaatsvond en verrijkten de informatie over de precieze omstandigheden. Om het bijzondere te observeren moest het nu worden geïnspecteerd en omgezet in een vruchtbare historische bron. Bijgevolg lichtten de beelden, veeleer dan een geschiedenis te illustreren die bekend was en met andere middelen was gedocumenteerd, een sluier op die leidde naar een duister vertrek vol tekens die verwijzen naar de doodsstructuur in S-21. De menselijke gezichten veranderden in schimmen, geprojecteerd in het schemerdonker van een museum dat hen van de folterplek verdreef en hen tot nomaden maakte, terwijl de permanente tentoonstelling in Phnom Penh onverbiddelijk verouderde. Buiten haar traumatische
(8) Hoewel aan de muren van Tuol Sleng positieve afdrukken van de originelen hingen, liet de kwaliteit van de kopieën die Niven en Riley bemachtigden toe om willekeurige gegevens te bestuderen waar voordien nauwelijks op was gelet, dit in tegenstelling tot de beschadigde reproducties van het museum. 
(9) Photographs of S-21, de tentoonstelling in het MoMA, liep van 15 mei tot 30 september 1997 en bestond uit 22 mug shots die waren uitvergroot op basis van negatieven van 6 op 6 . Hoewel toen al bekend was dat de fotograaf Nhem Ein ze had gemaakt, stond als onderschrift bij de foto's 'photographer unknown'. In juli van hetzelfde jaar presenteerde Les Rencontres Photographiques d'Arles $S$ - 21 . 100 portraits, met Christian Caujolle als curator.

(10) Het is de periode van het militaire einde van de Rode Khmers, voorafgegaan door de arrestatie en het showproces waarbij Pol Pot werd berecht door Ta Mok, 'de beenhouwer' (juli 1997), het interview van de journalist Nate Thayer met de zieke dictator en diens dood en crematie een jaar later. plek, opgehangen aan een muur van Gallery Three in het MoMA of de zetel van de Rencontres Photographiques d'Arles ${ }^{9}$, kon elke aparte foto, door haar uitvergrote formaat en haar isolering van de rest, in haar onherleidbaarheid worden bestudeerd. Maar tegelijk liep ze het risico te worden gecanoniseerd door het feit dat ze was omgeven door een soort aura. De gespecialiseerde pers spaarde haar kritiek op de curatoren niet en verweten hen harteloosheid, omdat ze de slachtoffers toonden zoals hun beulen hen hadden gezien, en op de koop toe als mensen zonder identiteit of land - louter als iconen.

In 1996 verscheen een bijzonder boek. De titel was afkomstig van een film van Roland Joffé die in 1984 een hit was, namelijk The Killing Fields. De auteurs waren niemand minder dan Riley en Niven. ${ }^{10}$ Ze maakten gebruik van de uitstekende kopieën die ze hadden bemachtigd en hun cataloguswerk vormde een uitnodiging om je op je eentje te verdiepen in de paginagrote gezichten van slachtoffers, afgewisseld met zwarte fotogrammen die de ervaring van een donkere tunnel nog versterkten en die deden denken aan het hypnotische kijken dat eigen is aan tentoonstellingen, zij het dan in solitaire lectuur. Bij die gezichten bleek de overdenking van Susan Sontag $(2004,73)$ maar al te waar:

Die Cambodjaanse mannen en vrouwen van alle leeftijden, onder wie veel kinderen, afgebeeld op een of twee meter afstand, gewoonlijk met hun bovenlichaam, kijken aldoor de dood in de ogen, staan aldoor op het punt te worden vermoord, worden eeuwig gekweld zoals in Titiaans De bestraffing van Marsyas, waarin het mes van Apollo eeuwigdurend op het punt staat neer te komen. En de toeschouwer bevindt zich in dezelfde positie als de slippendrager achter de camera; het is een misselijkmakende ervaring.

Die menselijke confrontatie had evenwel een tegenhanger: de abstrahering, het ontwortelen uit de plek van het trauma en het losrukken van het beeld uit de documentatie die het lot van het aanschouwde individu bezegelde (bekentenissen, notities, biografie of zelfs andere foto's). Er ontbrak net dat wat Cornell, Yale en DC-Cam al die jaren aan het beeld hadden trachten toe te voegen. In de ervaring van het boek The Killing Fields is, net als bij de tentoonstellingen, de foto het enige en unieke document; een blik isoleert het personage, situeert het in het heden zoals de fotografische daad het in het verleden situeerde, rukt het los uit de continuïteit van de vernietiging en verbant het uit het foltertoneel. Ernaar kijken is ongetwijfeld pijnlijk, maar het heeft iets gewichtigs; de intensiteit ervan is haast bedrieglijk.

\section{DE MENSELIJKE SOORT: BOPHANA, TEGENFIGUUR}

In 1996 draaide Rithy Panh de film Bophana: une tragédie cambodgienne, de eerste productie in het Khmer over de rampzalige periode. Panh, een overlevende die naar Frankrijk uitweek en wiens familie omkwam in de werkkampen, analyseerde het bewind van Democratisch Kampuchea uit het oogpunt van de eraan voorafgaande burgeroorlog en zijn eigen herinneringen. Daartoe koos hij als hoofdrolspeelster een figuur die hij in de geschriften van de Amerikaanse journalist Elizabeth Becker ontdekte: haar criminele biecht ging vergezeld van liefdesbrieven. Hout Bophana 


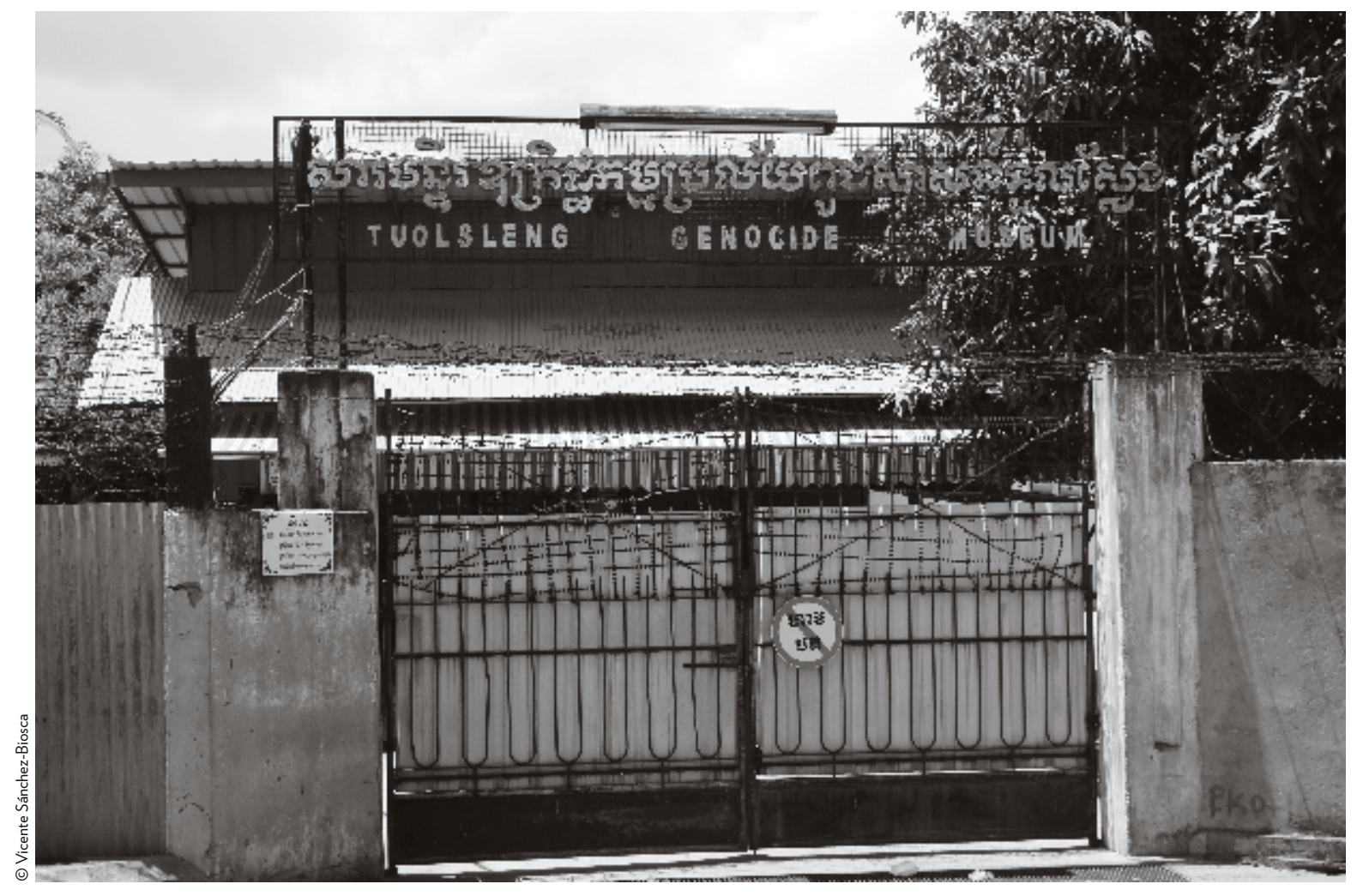

_ Hoofdingang van het voormalige folter- en

nam in die geschriften de identiteit aan van een personage uit de Ramayana en beschreef de revolutionaire samenleving als een allegorie van de rampen uit dat beroemde epische gedicht. Nummer 59, Bophana, Mom of Seda was opgegroeid in een familie van geletterde leraren. Toen de burgeroorlog uitbrak, zat ze vast in een gevaarlijke streek, werd verkracht door soldaten van het leger van Lon Nol, beviel van een zoontje en werkte voor de hulporganisatie Catholic Relief Services. Ze trouwde vervolgens met een neef van haar, op dat ogenblik een boeddhistische monnik die door Bophana's vader was geholpen. Toen Phnom Penh op 17 april 1975 viel, moest Bophana vluchten, terwijl haar man Ly Sitha onder de naam 'kameraad Seth' opklom op de ranglijst van de partij. Vluchtige ontmoetingen, een valse vrijgeleide die tussen de paperassen van Ly Sitha werd gevonden, en de verbitterde brieven bleken onomstotelijke bewijzen toen de beschermheer van Sitha in ongenade viel. Op 19 september 1976 werd Seth aangehouden, naar Tuol Sleng gebracht, gefolterd en officieel 'vernietigd' op 18 maart 1977. Bophana werd gearresteerd op 12 oktober 1976 en geëlimineerd op dezelfde dag als haar geliefde, al zal geen van beiden zich bewust zijn geweest van het feit dat ze tijdens de laatste ogenblikken van hun leven zo dicht bij elkaar waren.

In het begin filmt Panh hoe Bophana's oom in de gangen van S-21 tussen de dicht opeengepakte gezichten het mug shot van zijn nicht identificeert, met haar 
_ Chum Mey, overlevende van S-21, verkoopt zijn mémoires aan een stand naast de hoofdingang.
(11) Het nieuwe volk was, in tegenstelling tot het oude (dat landelijk en ongeletterd was), volgens de Rode Khmers een overblijfsel van het kapitalisme, voorgoed verloren en voorbestemd om onverbiddelijk vernietigd te worden. Tot dat volk behoorden leraren, dokters, verplegers, ingenieurs en in het algemeen alle geletterde mensen.

(12) Jaren later zou Rithy Panh een Frans-Cambodjaans centrum oprichten met zetel in Phnom Penh, een archief van de eerste orde voor audiovisueel onderzoek naar de Rode Khmerperiode. Met haar vrouwennaam doopte hij het Bophana Audiovisual Resource Center (http://www.bophana.org/).

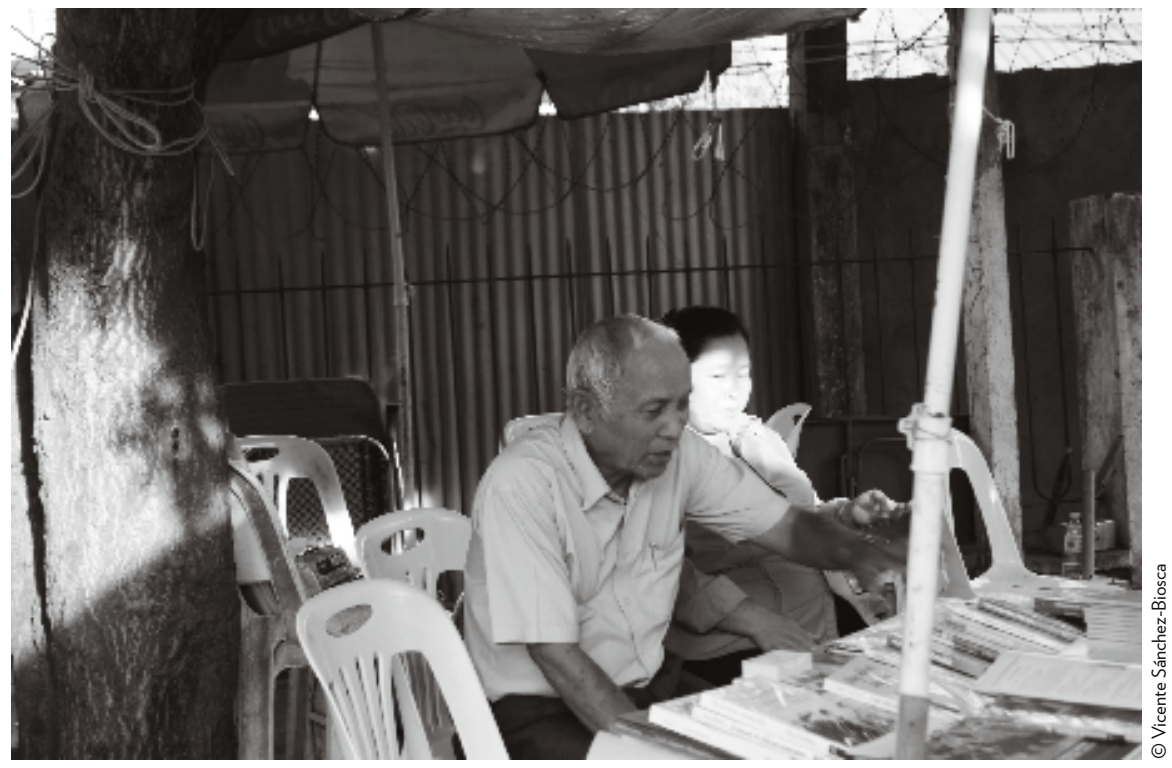

waardige, serene gelaat. De oude man denkt terug aan hun afscheid in Phnom Penh toen dat in de greep van de paniek was, en vervolgens gaat de film terug in de tijd naar de tragedie van Bophana. Zoals in een wedergeboortefantasie maakt het gezicht van de gedetineerde plaats voor een idyllische landelijke omgeving, met het fraaie silhouet van een jonge vrouw die op de fiets een ritje langs de rivier maakt. Door de vrouwenstem die de noodlottige liefdesbrieven leest en een andere verteller die het verslag doet van haar leven, de vervolging en het complot, wordt deze geletterde en verfijnde figuur een zinnebeeld van de deugdzame Cambodjaanse geest van weleer, zo verfoeid door de Rode Khmers.

Met zijn camera vat Panh Bophana's trekken zoals andere, barmhartiger ogen die zien: die van de schilder Vann Nath, die haar bevallig met houtskool neerzet. In de ogen van Panh is Bophana een condensaat van de gevoelige, gecultiveerde geest van Cambodja, die de nieuwe leiders 'het nieuwe volk' noemden, de sociale klasse die moest verdwijnen. ${ }^{11}$ De term die ze gebruikten om het bevel tot executie te geven vat het mechanische mysterie van de onrechtvaardigheid samen: kamtech betekent niet alleen kapot maken; het houdt wegvagen in, verpulveren zodat er geen enkel spoor overblijft. De geheimen van de Angkar worden, net als die van het Derde Rijk, in hun eigen taal met vuur aangeduid.

Op die manier wordt het antropometrische beeld van Bophana gered door andere blikken, die het bevrijden uit de fiche waarmee werd beslist over haar dood en die deze tegelijk documenteerde. Haar tragische verhaal draait om een contrarevolutionair woord, een gevoel waar in Democratisch Kampuchea geen plaats voor was: de liefde. ${ }^{12}$ 
Het gezichtenarchief van Tuol Sleng onderging nog een andere verandering; het werd namelijk ingezet ter ondersteuning van beschuldiging voor de rechtbank. Met het oprichten van de Extraordinary Chambers in the Courts of Cambodia (ECCC) werd de oude droom om de Rode Khmerleiders te berechten werkelijkheid. Het succes daarvan, het eindpunt van een lange weg vol hindernissen, was vooral te danken aan het hardnekkige onderzoek dat DC-Cam had verricht of in goede banen geleid. De eerste zaak werd in 2009 geopend tegen Kaing Guek Eav, alias Duch, de voormalige directeur van S-21. Tien jaar eerder, in 1999, was een christelijke bekeerling die samenwerkte met een ngo en luisterde naar de naam Hang Pin, door de fotograaf Nic Dunlop herkend als de geduchte gevangenisverantwoordelijke. Na een video van diezelfde Dunlop en een nieuwe ontmoeting, ditmaal in het gezelschap van de journalist Nate Thayer, werd hij door de autoriteiten gearresteerd. Het geval-Duch (001) betekende dat die sinistere periode in het Cambodjaanse leven op onalledaagse wijze in scène werd gezet - een periode die als een traumatische herinnering haar schaduw over het heden wierp. Het hield een openbare erkenning van de slachtoffers in, opgezet met een ongeziene mediaverslaggeving, en een poging om de juridische vervolging te vertalen in een instrument van reflectie en (op lange termijn ook) nationale verzoening. ${ }^{13}$

Zonder afbreuk te doen aan vroegere initiatieven of strategieën die ik eerder besprak, versterkten de slachtoffers van S-21 een aantijging die werd ondersteund door de stemmen van overlevenden, familieleden en getuigen. Alsof die slachtoffers, dertig jaar na hun dood, uit de as herrezen om hun beulen met een vernederde blik opnieuw te beschuldigen. Het parcours dat in het tribunaal ten einde komt, dringt op zijn weg bovendien door in andere sferen die binnen de burgermaatschappij als klankkast dienen voor de beschuldigende blik. Zo gaan de mug shots door de handen van wie bij het moordproces betrokken is (of die nu al dan niet is beschuldigd), circuleren ze op kantoren van advocaten en procureurs, en bereiken de persagentschappen. Vooral de media vergroten op exponentiële wijze het bereik van de aantijgingen, die nu een precieze functie krijgen en gaan dienen als bewijsmateriaal voor een strafrechtelijke uitspraak. Tijdens dat traject komen de foto's in het bezit van de familieleden, die via de herinnering een soort verlossing ervaren.

Uit de reconstructies van de daden waarvan kameraad Duch in de afgesloten gevangenisruimte de hoofdrolspeler was, blijkt dat de rechtspraak de misdaden in S-21 symbolisch recupereerde. Net zo synthetiseert een beeld vermoedelijk de nieuwe functie van de foto's van de S-21-gefolterden: de voormalige directeur laat de portretten door zijn handen glijden, alsof ze hem om een verklaring vragen. Die botsing van blikken, door de camera's doelbewust vastgelegd, is radicaal anders dan de eerste blik: Duch had ze destijds bekeken toen ze waren vastgehecht aan de fiches waarmee hij de reeks ondervragingen en executies bepaalde, en ziet ze nu terug, uitvergroot en in kopieën van hoge kwaliteit. Hij tracht zijn geheugen aan te spreken, maar in de loop van die dertig en nog wat jaren is er iets verdwenen uit diezelfde
(13) Ta Mok stierf in juli 2006 in de gevangenis, nog voor de oprichting van het tribunaal; leng Thirith werd in september 2012 krankzinnig verklaard; leng Sary stierf op 14 maart 2013, toen het proces nog volop aan de gang was. Nuon Chea en Khieu Samphan werden op 7 augustus 2014 veroordeeld door het VN-tribunaal in Phnom Penh. Zij kregen levenslang. Mogelijke andere processen staan in het vooruitzicht, maar de namen van de beschuldigden zijn nog niet bekendgemaakt. 
geest, namelijk het gevoel de gezichten van vijanden te onderzoeken. Tussen die twee blikken van hetzelfde individu gaapt met andere woorden een kloof, niet alleen wat het statuut van de bekeken personen betreft, maar ook van het kijkvermogen. Kijken was toen beslissen over het ritme van de vernietiging; nu betekent het zijn verantwoordelijkheid opnemen. Het kijkvermogen is in zekere zin van richting veranderd. Dat Duch in het openbaar een mea culpa inzet en (al dan niet oprecht) de slachtoffers om vergiffenis smeekt, veroorzaakt een verandering in het sociale weefsel dat zich om het gerechtshof heeft verzameld. Toch kan er geen sprake zijn van substitutie of uitvlakking: in die ultieme verandering komen alle blikken van toen weer tot leven, als een palimpsest dat een ogenblik naar boven komt en onmiddellijk weer vervaagt. Het zijn blikken die zonder ophouden andere blikken insluiten.

Het proces-Duch was een modderpoel waar beroemde figuren zich in vastliepen. De Franse antropoloog François Bizot, in 1973 gevangengezet in het oerwoud en om raadselachtige redenen door Duch vrijgelaten, was geschokt door diens aanhouding en snelde toe om hem te zien en te informeren naar de reden voor zijn gratieverlening - het vergiftigde geschenk waarmee hij aan de dood was ontsnapt (Bizot 2011). De cineast Rithy Panh, die zijn film S21. La machine de mort Khmère rouge (2003) rond deze tegelijk demiurgachtige en afwezige figuur had geconstrueerd, zag zich verplicht om hem te ontmoeten, te spreken, te filmen; hij worstelde met de dichte netten die deze voormalige wiskundeleraar spande. Alleen het monteren van zijn film Duch, le maitre desforges de l'enfer (2011) hielp hem om de beklemming tegen te gaan die de verhullende strategie van Duch bij hem opwekte (Panh \& Bataille 2011, 233-234). François Roux, een strijdbaar advocaat van de geweldloosheid, ging de uitdaging aan om de beul te verdedigen op voorwaarde dat die schuldig zou pleiten, in de hoop dat dit een voorbeeld van bevel van hogerhand zou worden in plaats van een grond voor strafuitsluiting. Door een onverwachte ommezwaai van Duch en Kar Savuth, zijn Cambodjaanse advocaat, werd Roux van de verdediging ontslagen. Niemand maakte zich illusies: zich vragen stellen over Duch betekende ook zich vragen stellen over zijn eigen donkere kanten, want stuk voor stuk wisten ze dat Duch, net als Adolf Eichmann een halve eeuw voordien, sprak vanaf de onbestendige, troebele grens tussen menselijkheid en onmenselijkheid. Hoe dichter je bij hem stond en hoe meer je verwikkeld raakte in zijn betoog, zijn medelijden, zijn lach, des te meer groeide het menselijke onbehagen, omdat iets de diepten van elk menselijk wezen besmet. Zoals Roux het woordelijk uitdrukte: in de figuur van Duch herkennen we (al dan niet) onze broeder in de schoot van de mensheid. Tot hun eigen verbazing en verontrusting stelden ze vast dat ze faalden, dat hun geweten maar moeilijk heelde.

Iets gelijksoortigs gebeurt met de slachtoffers. Van de meer dan 120000 personen die in S-21 omkwamen, waren een aanzienlijk aantal meedogenloze en fanatieke Rode Khmers die in ongenade waren gevallen, vaak ondervragers die uiteindelijk werden geëxecuteerd. Er is dus geen enkele garantie dat je bij het bekijken van die gezichten onschuldigen aanschouwt. Dat blijkt bijvoorbeeld uit het uiterst lijvige dossier van de minister van Propaganda Hu Nim, naar aanleiding van een zuivering opgepakt op 10 april 1977, ondervraagd, gefolterd en uiteindelijk geëxecuteerd op 
6 juli 1977 (Chandler, Kiernan \& Chathou 1988). Die grijze zone, om de term op te pikken die Primo Levi in De verdronkenen en de geredden bezigde met betrekking tot de uitroeiing van de Joden, wordt in het geval van S-21 nog ondoorzichtiger en onbeslister van aard. Niemand die hoop koestert voor of werkt aan nationale verzoening kan die niemandszone (of preciezer uitgedrukt: die zone van velen) negeren.

\section{ARTEFACTEN, AFBEELDINGEN, ICONEN}

De mug shots van Tuol Sleng behoren tot de zeldzame voorwerpen die van de vernietigingsperiode bewaard zijn gebleven. De slachtoffers zijn verdwenen, er blijven wat nauwelijks herkenbare beenderen over; resten nog documenten die door de vasthoudendheid van sommigen tot bewijsmateriaal worden voor de aanklacht, een instrument van historisch begrip en een oefening in collectief geheugen. De antropometrische beelden daarentegen tonen de fysieke trekken, de gelaatsuitdrukking, het lichaam en de letsels van personen die in S-21 werden gefolterd en vermoord. Daarom zijn de foto's in de eerste plaats semiotische objecten die we moeten onderzoeken op basis van hun voorstellingscodes (schaal, hoek, verhoudingen, afsnijding, lichtsterkte, belichtingstijd enz.). Ze bestuderen helpt bij het nadenken over hoe de Rode Khmers hun vijanden bekeken en dus ook opvatten. Maar die representatie volstaat niet om te verklaren waarom de foto's zo ongemeen krachtig zijn. In de foto's krijgt een tweede niveau gestalte: het onherhaalbare moment van botsende blikken; een lichtje dat registreert wat het wezen voor de camera uitdrukte met een al dan niet bewust gebaar, de laatste maal dat het werd gefotografeerd, niet vóór het sterven maar om te sterven. Daardoor krijgt de fotografische daad iets performatiefs: veeleer dan een vijand te beschrijven, schept ze die; veeleer dan een aanzet te geven tot een fiche van de gedetineerde, betekent ze diens doodvonnis. De foto voert ons dus terug naar het ogenblik, maar daarachter tekent zich dreigend af wat nog te gebeuren staat. Zelden werd de idee van Barthes - elke foto van een mens stelt met angstwekkende zekerheid: 'Je zult sterven' - zo onverbiddelijk en nadrukkelijk bevestigd.

En toch zijn die foto's ook objecten. Ze oxideren jarenlang in opslagplaatsen, hun negatieven worden opgevist om er nieuwe en contrastrijker kopieën van te maken die naar believen worden uitvergroot om het voordien onwaarneembare detail beter te doen uitkomen; daarna doen ze ingelijst de ronde van musea en galerieën, laten zich als relikwieën aaien door de handen van zij die de geportretteerden beminden, gaan - en hier treedt een verontrustende besmetting op - door de handen van de beulen. Het zijn overblijfsels van een naakt leven die - hoewel het wel spoken lijken wanneer ze op bepaalde webpagina's als een lijkstoet defileren $^{14}$ - in andere gevallen gestalte krijgen, de ruimte opvullen, zich gedragen als materiële sporen van het verleden.

In een passage uit Shoah (Claude Lanzmann 1985) neemt de historicus Raul Hilberg één enkel, vergeeld blad ter hand, een dienstorder - zo zegt hij - van een trein des doods. Het blad vermeldt precieze tijdschema's, namen van stations, nummers van wagons en van eenheden, dat wil zeggen de lichamen die erin worden vervoerd. De
(14) Let bijvoorbeeld op de presentatie van het project van Yale University: http://cgp.research.yale.edu/cgp/ cts/cts_slideshow.jsp Een andere strategie is te vinden in de fotosectie van de Tuol Sleng-webstek:

http://www.tuolsleng.com/ photographs.php (beide pagina's geraadpleegd 25 januari 2014). 


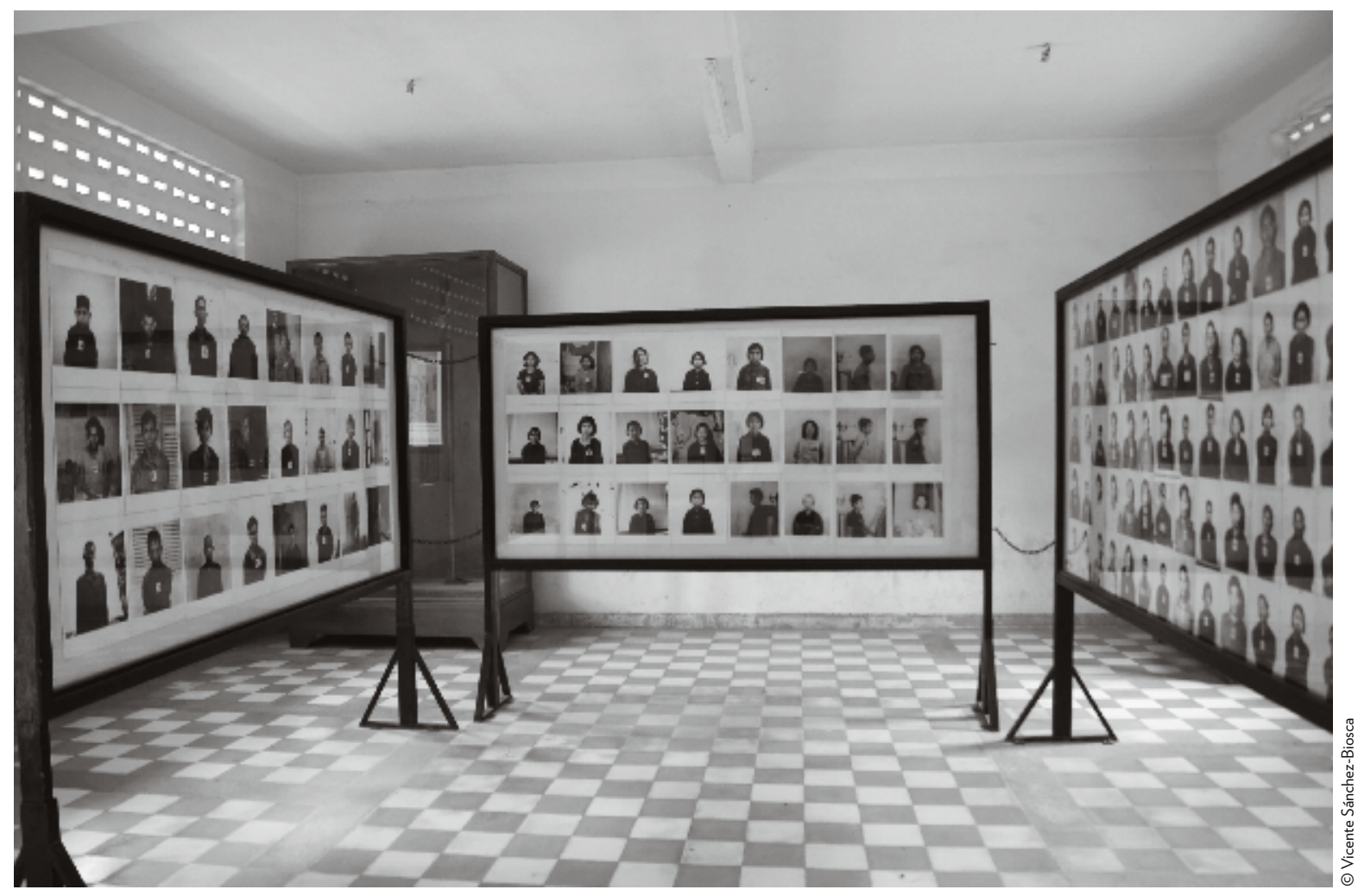

_ Tentoonstellingsruimte in het Tuol Slengmuseum (Phnom Penh). De mug shots van de Rode Khmerfotografen zijn er te zien. historicus ontcijfert nauwgezet de afstanden en projecteert ze op een denkbeeldige kaart van de deportatie; hij leest geheime codes zoals de twee letters LZ (leerer Zug, lege trein) die een concentraat van de misdaad verbergen, want ze verwijzen naar een trein waarvan de wagons in Treblinka zijn uitgeladen en die leeg terugkeert. Hilberg interpreteert niet alleen het document; hij vult er de leemten van in, doorprikt de bureaucratische ondoorgrondelijkheid en laat de stilten spreken. Wat deze Holocaustonderzoeker al bij al nog het meest fascineert, is het feit dat het om een origineel gaat, waarvan evenveel kopieën moeten hebben bestaan als er ambtenaren bij de dienstorder betrokken waren. Daar het authentiek is, ging het door de handen van een deportatieambtenaar en alleen zo kon die zijn taak volbrengen. Voor het met andere woorden een document werd over wat geschiedde (het lijden), was dit blad een bevel, een performatief geschrift: het bericht niet, maar veroorzaakt. Het vasthouden en aanraken terwijl je het ontcijfert, is je opstellen op de plaats van de beul, hem vergezellen in zijn mentale proces, hem zijn vernietigingswapen uit handen rukken, zij het dan ongetwijfeld te laat.

De foto's van Tuol Sleng zijn informatieweefsels die iets zeggen over de identificatie van de gedetineerden. Daarom moeten we ook hun marges analyseren, raden naar wat zich buiten het beeld bevindt, reconstrueren of haast fantaseren over wat nauwelijks merkbaar aan een rand van de beelduitsnede naar binnen sluipt. 
Anderzijds zijn het daden die een persoon tot een schuldige maakten en hem in een uitzichtloze val duwden. Maar in laatste instantie zijn het ook materiële sporen die werden losgerukt uit de duistere wereld van de Rode Khmers, objecten die door hen werden vervaardigd, bijgeknipt, zorgvuldig bestudeerd, becommentarieerd, geïnventariseerd en beduimeld. Er blijft nog iets van de sound and fury aan hangen van wie ze maakte, en van de angst van wie ze onderging, of die nu schuldig was of niet. Zoals al die objecten waarvan de oorlogsmusea uitpuilen, zijn het volgens sommigen fetisjen, volgens anderen dan weer pijnlijke materie die onder de huid kruipt. Wat we er ook mee doen, nooit zullen we erin slagen om de kreten te doen verstommen.

\section{BIBLIOGRAFIE}

- AAVV, Fichés? Photographie et identification 1850-1960, Parijs: Perrin, 2011.

- François Bizot, Le silence du bourreau, Parijs: Flammarion, 2011.

- David Chandler, Voices from S-21. Terror and History in Pol Pot's Secret Prison, University of California Press, 1999.

- David Chandler, Ben Kiernan \& Boya Chathou, Pol Pot Plans the Future. Confidential Leadership Documents from Democratic Kampuchea, 1976-1977, New Haven Yale University Souheast Asia Studies, 1988.

- Thierry De Duve, 'Art in the Face of Radical Evil', October 125, 2008, 3-23.

- Nic Dunlop, The Lost Executioner. A Journey to the Heart of the Killing Fields, New York: Walker, 2006.

- Michelle Q. Hamers, Do nothing, sit still, and wait for my orders. The role of photography in the archive practices, historiography, and memory of Democratic Kampuchea 1975-1979, MA Thesis, Leiden Universiteit 2011.

- Rachel Hughes, 'The abject artifacts of memory: photographs from Cambodia's genocide', Media, Culture \& Society 25, 2003, 23-44.

- Ben Kiernan, The Pol Pot Regime. Race, Power, and Genocide in Cambodia under the Khmer Rouge, 1975-1979, Chian Mai: Silkworm Books, 1996.

- Vann Nath, Dans l'enfer de Tuol sleng. L'inquisition khmère rouge en mots et en tableaux, Parijs: Calmann-Lévy, 2008.

- Rithy Panh \& Christophe Bataille, L'élimination, Parijs: Grasset, 2011.

- Christopher Riley \& David Niven, The Killing Fields, Santa Fe: The Twin Palms, 2006.

- Susan, Sontag, Regarding the Pain of Others, Madrid: Santillana, 2004.

- Rafael R. Tranche, "Los huesos gritan, la carne llama” o la memoria del horror. S-21, la máquina de matar jemer roja (R. Panh 2002)', in V. Sánchez-Biosca (red.), Figuras de la aflicción humana, Valencia: MuVIM, 2011, 83-88.

- Patrizia Violi, 'Il visitatore como testimone. II Tuol Sleng Museum of Genocide Crimes a Phnom Penh', in Maria Pia Pozzato (red.), Testi e memoria. Semiotica e costruziones politica dei fatti, Bolonia: II Mulino, 2010, 13-44. 